\title{
Environmental controls on Emiliania huxleyi morphotypes in the Benguela coastal upwelling system (SE Atlantic)
}

\author{
Jorijntje Henderiks ${ }^{1, *}$, Amos Winter ${ }^{2}$, Malte Elbrächter ${ }^{3}$, Rainer Feistel ${ }^{4}$, \\ Anja van der Plas ${ }^{5}$, Guenther Nausch ${ }^{4}$, Ray Barlow ${ }^{6}$ \\ ${ }^{1}$ Department of Earth Sciences, Uppsala University, Villavägen 16, 75 236, Uppsala, Sweden \\ ${ }^{2}$ Department of Marine Sciences, University of Puerto Rico, Mayaguez, PR 00681-9000, Puerto Rico \\ ${ }^{3}$ Alfred Wegener Institute for Polar and Marine Research, Wattenmeerstation Sylt, Hafenstr. 43, 25992 List/Sylt, Germany \\ ${ }^{4}$ IOW-Leibniz Institute for Baltic Sea Research, Warnemünde, 18119 Rostock, Germany \\ ${ }^{5}$ NatMIRC, MFMR (National Marine Information \& Research Centre, Ministry of Fisheries \& Marine Resources), PO Box 912, \\ Swakopmund, Namibia \\ ${ }^{6}$ Bayworld Centre for Research \& Education, 7806 Cape Town, South Africa
}

\begin{abstract}
Two distinct morphotypes of the coccolithophore Emiliania huxleyi were observed as part of the phytoplankton succession offshore of Namibia, where coastal upwelling created strong gradients in sea surface temperature (SST), salinity, and nutrient conditions. The sampled surface waters hosted a characteristic succession of phytoplankton communities: diatoms bloomed in newly upwelled waters above the shelf, whereas dense coccolithophore communities dominated by $E$. huxleyi were found farther offshore, in progressively aging upwelled waters. A substantially calcified E. huxleyi morphotype (labeled Type A*) dominated plankton assemblages at stations influenced by upwelling, that immediately succeeded coastal diatom blooms. This morphotype caused a chlorophyll and 19'-hexanoyloxyfucoxanthin (19'-HF) maximum with $>1 \times 10^{6}$ cells $^{-1}{ }^{-1}$, straddling a pycnocline at $17 \mathrm{~m}$ depth where the in situ N:P ratio was $\approx 13$. Farther offshore, within $<20$ nautical miles distance, populations of Type $\mathrm{A}^{*}$ drastically declined, and a more delicate morphotype with thin distal shield elements and open central area (Type B/C) was found. This morphotype was most

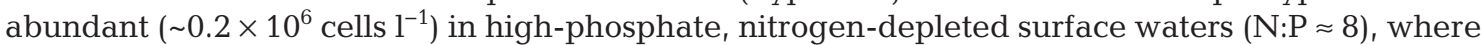
it co-existed with other coccolithophores, most notably Syracosphaera spp. Extensive surface blooms of coccolithophores observed by satellites in the same region in the past were identified by microscopy as being produced by E. huxleyi and S. pulchra. However, blooms of E. huxleyi at greater depths in the euphotic zone, such as those observed in this study, will go undetected by satellites and thus underestimate coccolithophore biomass and calcification within upwelling regions.
\end{abstract}

KEY WORDS: Emiliania huxleyi · Morphology · Ecology · Plankton succession · Coastal upwelling · Namibia

\section{INTRODUCTION}

Coccolithophores (marine calcareous haptophyte algae) play an important role in the global carbon cycle as primary producers and marine calcifiers. Recent concerns about climate change and the effects of rising ocean temperatures and lowering ocean $\mathrm{pH}$ (ocean acidification) on marine productivity and calcification (e.g. Feely et al. 2004, Orr et al. 2005, Rost et al. 2008) have triggered an urgent and renewed interest in coccolithophore ecology and physiology (e.g. Poulton et al. 2007, Cook et al. 2011). It is currently not known to what extent natural coccolithophore populations will be able to adapt to 
projected changes in their environment, but observations over the past decades seem to suggest geographical shifts in coccolithophore occurrences and species composition (e.g. Smyth et al. 2004, Cubillos et al. 2007). Environmental controls on coccolithophore physiology and coccolith calcification have been tested in numerous experimental studies that primarily used monoclonal cultures of the species Emiliania huxleyi (see reviews by Paasche 2001, Zondervan 2007). However, the extrapolation of laboratory-based results to the scales and dynamics of the real ocean remains speculative (Langer et al. 2009). Another approach is to investigate environmental controls on natural populations in areas that have sharp physical and chemical gradients.

Emiliania huxleyi (Lohmann) Hay and Mohler is considered the most successful coccolithophore in today's pelagic and neritic waters, ranging from polar to tropical latitudes (Brand 1994, Cubillos et al. 2007). This species evolved 268000 years ago and has been globally dominant since $\sim 78000$ years ago (Thierstein et al. 1977). The extensive genetic diversity of this taxon probably allows it to rapidly respond and adapt to environmental changes by the migration of genetically distinct populations with different environmental tolerances, and as such maintain blooms on a 'cosmopolitan' scale (Medlin et al. 1996, IglesiasRodríguez et al. 2006, Cook et al. 2011). E. huxleyi also exhibits significant morphological diversity, in terms of coccolith shape, size, and degree of calcification. To date, 5 different morphotypes are known to remain stable in culture (Type $A, B, B / C, C$, and $R_{\text {; }}$ Young et al. 2003) of which at least 3 have shown to be genetically distinct (Schroeder et al. 2005, Cook et al. 2011). Different E. huxleyi morphotypes have been reported in environmentally diverse regions and/or seasons within surface waters of the North Atlantic Ocean (e.g. McIntyre \& Bé 1967, van Bleijswijk et al. 1991, Beaufort \& Heussner 2001), Southern Ocean (Findlay \& Giraudeau 2000, Cubillos et al. 2007, Cook et al. 2011), and Pacific Ocean (Okada \& Honjo 1973, Winter 1985, Hagino et al. 2005, Beaufort et al. 2008). Hence, it is important to differentiate between morphotypes or ecotypes in natural samples in order to better understand the genetic diversity and ecophysiological plasticity of E. huxleyi.

Mitchell-Innes \& Winter (1987) were the first to report on large populations of Emiliania huxleyi that dominated mature upwelling waters offshore of South Africa, but these authors made no distinction between morphotypes. The present study reports on the occurrences and inferred environmental preferences of 2 E. huxleyi morphotypes (Type $\mathrm{A}^{*}$ and
Type B/C) in water-column samples separated by only $\sim 20$ nautical miles $(<40 \mathrm{~km})$ collected in October 2000, during an upwelling season offshore of Namibia, SW Africa. This upwelling region is characterized by large gradients in sea surface temperature (SST), nutrient availability, and $\mathrm{CO}_{2}$ concentrations within a relatively small geographic area.

Surface waters off Namibia are part of a major wind-driven eastern boundary upwelling system (the Benguela system) and encompass a wide range of different oceanographic regimes. Seasonal coastal upwelling introduces cold, nutrient-rich waters that are essential in sustaining high primary productivity and large fish stocks in this region (e.g. Clark 2006). North of $25^{\circ} \mathrm{S}$, upwelling mainly occurs from March to November (Shannon 1985). During periods of active upwelling, a hydrographic front separates cool, recently upwelled waters closest to shore from waters that represent a mixture of upwelled and oceanic waters above the outer shelf: the 'mixed' or intermediate domain (Hagen et al. 1981, Giraudeau $\&$ Bailey 1995). The cold northward Benguela current follows the direction of the south-east trade winds (SET), driven by the air-pressure gradient between the South Atlantic Anticyclone and the Kalahari Low (for further details see Feistel et al. 2003). Above the continental slope, warmer oceanic waters prevail that are associated with the South Atlantic subtropical gyre. Upwelling conditions vary considerably from year to year (Hagen et al. 2001), but the year 2000 was considered particularly intense (Emeis et al. 2007).

\section{MATERIALS AND METHODS}

Phytoplankton and hydrographic samples were collected from 13 to 30 October 2000 during RV 'Meteor' cruise 48, Leg 5. A sampling campaign was carried out on 5 transects perpendicular to the Namibian coast and 1 transect parallel to the coast following the $200 \mathrm{~m}$ isobath to sample contrasting environments from recently upwelled to oceanic waters (Alheit 2000). Additional details are available from the preliminary report of the workshop held at Swakopmund, Namibia, immediately after the cruise (Hansen \& Klingelhoeffer 2000). Here, we investigated a subset of 33 samples, from 20 stations along 2 transects at about $21^{\circ} \mathrm{S}$ (Transect 3; sampled on 21 October) and $25^{\circ} \mathrm{S}$ (Transect 5; sampled on 27 October), plus 5 additional stations between 22 and $23^{\circ} \mathrm{S}$ (Fig. 1). Stations along Transects 3 and 5 are about 10 nautical miles apart $(\sim 18.5 \mathrm{~km})$. In situ tempera- 
ture, salinity, oxygen, and chlorophyll a (chl a) were determined by CTD casts. Water samples were taken from CTD bottles for the analysis of coccolithophores, in situ nutrient concentrations, and bio-optical characteristics. Inorganic nutrient concentrations (phosphate, nitrite, nitrate, ammonium, and silicate) were measured with standard colorimetric manual methods (Rohde \& Nehring 1979, Grasshoff et al. 1983). The fixed-inorganic-nitrogen deficit was calculated from in situ nutrient concentrations, using the equation $\mathrm{N}$-deficit $=16 \times[$ phosphate $]-([$ nitrate $]+[$ nitrite $]$ + [ammonium]), where 16 is the Redfield ratio of fixed inorganic nitrogen to phosphate (Kuypers et al. 2005). Analysis of pigments followed the reverse phase liquid chromatography procedure described by Barlow et al. (1997). Pigments were detected at 440 and $665 \mathrm{~nm}$ and identified by retention time and on-line diode array spectra. Barlow et al. (2006) provided further details concerning all pigment data acquired during this cruise. In the present study, we focused on in situ concentrations of 19'-hexanoyloxyfucoxanthin (19'-HF), a marker pigment for openocean prymnesiophytes including the coccolitho-

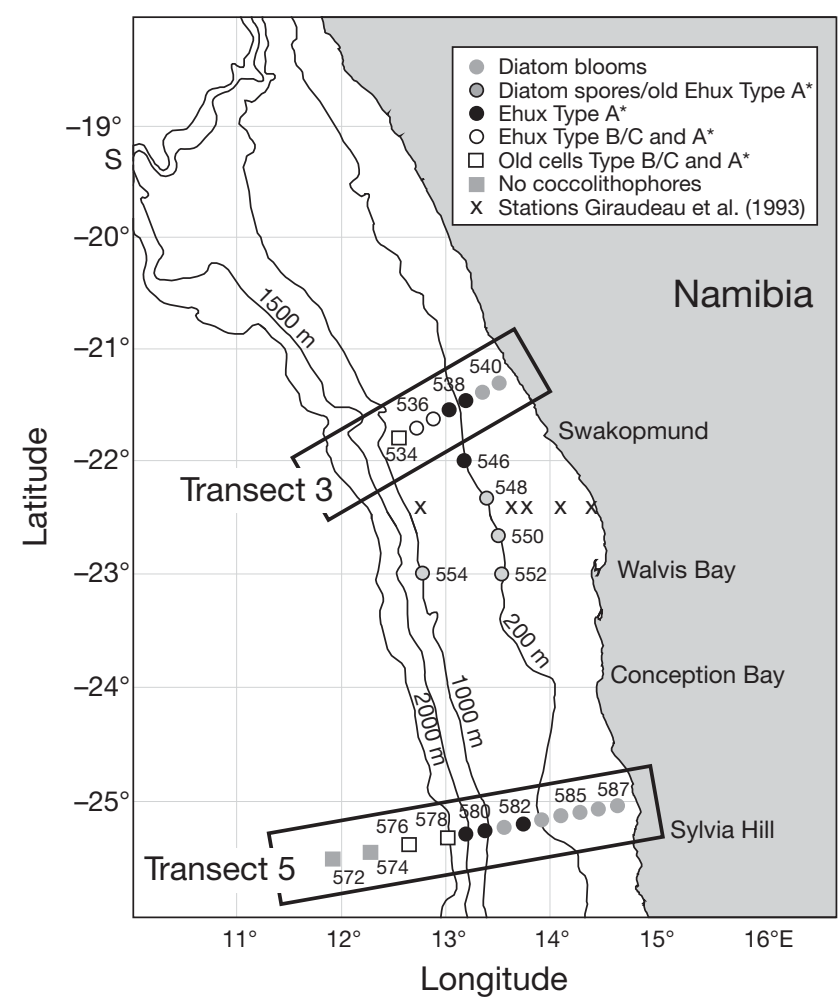

Fig. 1. Stations sampled during RV 'Meteor' cruise 48/5 and bathymetry off Namibia. Stations along Transects 3 and 5 were about 10 nautical miles $(\sim 18.5 \mathrm{~km})$ apart and revealed dynamic phytoplankton successions during active coastal upwelling in October 2000. Ehux: Emiliania huxleyi phore Emiliania huxleyi (Jeffrey \& Vesk 1997, Barlow et al. 2004, Van Lenning et al. 2004, Cook et al. 2011).

Coccolithophore water samples (500 to $1000 \mathrm{ml}$ of seawater) were filtered onto $0.45 \mu \mathrm{m}$ pore size Millipore $^{\mathrm{TM}}$ filters using low-pressure vacuum. Filters were air-dried, and then small sections were mounted on an aluminum stub and coated with $\mathrm{Au} / \mathrm{Pd}$ prior to scanning electron microscopy (SEM) analysis (Philips XL-30-SEM).

Coccolithophore cell abundance (no. cells $\mathrm{l}^{-1}$ seawater) and corresponding 95\% confidence intervals were estimated following the recommendations of Bollmann et al. (2002). Cell counts were performed on 300 to 600 fields of view (FOV) at $1200 \times$ magnification along random trajectories. This corresponds to a filter area of 2.2 to $4.2 \mathrm{~mm}^{2}$ and 5.7 to $11.5 \mathrm{ml}$ of seawater analyzed per sample. Analysis of cell counts at regular intervals (50 FOV increments) revealed that coccolithophores were evenly distributed on the filters, with stable total cell estimates after a total of $4 \mathrm{ml}$ seawater was analyzed. Most coccospheres in our counts were determined to the species level, although a few taxa could only be identified to genus.

Detailed morphometric analysis of Emiliania huxleyi populations was performed on 14 key samples. For each sample, at least 50 individual E. huxleyi coccospheres were randomly selected and photographed digitally at a calibrated magnification of $8000 \times$. Biometric measurements of coccosphere diameter and coccolith size (distal shield length, DSL, in $\mu \mathrm{m})$ measured on at least 2 coccoliths per sphere) were performed using ImageJ software. At the given settings, the image pixel resolution equaled 0.021 $\mu \mathrm{m}$. The size data were grouped by morphotype, as determined by the morphological characteristics of the distal shield elements and central area structure. In order to identify any relationship of environmental variability to coccolithophore morphology, size, abundance, and the distributions of these, we performed principal component analysis ( $\mathrm{PCA}_{i}$ Varimax rotation) and analysis of variance (ANOVA) using SYSTAT 13 and Microsoft Excel software.

\section{RESULTS}

\section{Phytoplankton succession}

The CTD seawater temperature and nutrient profiles demonstrate that coastal upwelling was active at the time of sampling (Fig. 2). As expected, coolest, nutrient-rich surface waters were found closest to shore above the shelf, while near-vertical isotherms 
are indicative of strong thermal fronts between the coast and stations farther offshore along Transects 3 and 5 (Fig. 2a,b). Major nutrient concentrations ranged from 0.5 to $2.5 \mu \mathrm{M}$ for phosphate (Fig. 2c,d), and 0 to $30 \mu \mathrm{M}$ for nitrate (Fig. 2e,f). CTD profiles of turbidity and chlorophyll fluorescence also revealed that the highest phytoplankton biomass was concentrated between the surface and $\sim 60 \mathrm{~m}$ water depth, closely associated with the local density profiles and depth of pycnoclines (Fig. 3a).

Diatom blooms typically populated the nearshore stations (Figs. $1 \& 3 \mathrm{~b}$ ), with cell densities up to $\sim 75000$ cells $1^{-1}$ at Transect 3 , and roughly (1 to 5) $\times$

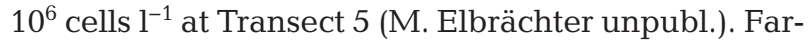
ther offshore, total coccolithophore standing stocks

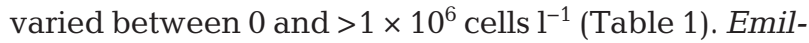
iania huxleyi dominated most coccolithophore assemblages, which is corroborated by in situ concentrations of the 19'-HF pigment (Fig. 4a). The highest cell con- centrations were found at stations with no or little in situ nitrogen deficiency (Fig. 4b).

Two different morphotypes of Emiliania huxleyi occurred within 20 nautical miles $(37 \mathrm{~km})$ of each other (Figs. $1 \&$ 4 , Table 2). A heavily calcified $E$. huxleyi with short, I-shaped distal shield elements and heavily calcified inner tube elements that extend irregularly into the central area (Fig. 5a) dominated phytoplankton assemblages above the outer shelf and slope. The observed morphological features are highly consistent within and between the sampled populations. This morphotype could be a variant of E. huxleyi Type A (cf. Young et al. 2003), which is known to exhibit variation in morphology of the central tube and a range of degree of calcification and malformation or secondary dissolution (e.g. Young 1994, Yang et al. 2004). Unfortunately, no cells were isolated and kept in culture, so we were not able to test the phenotypic stability of this form nor its

Transect 3

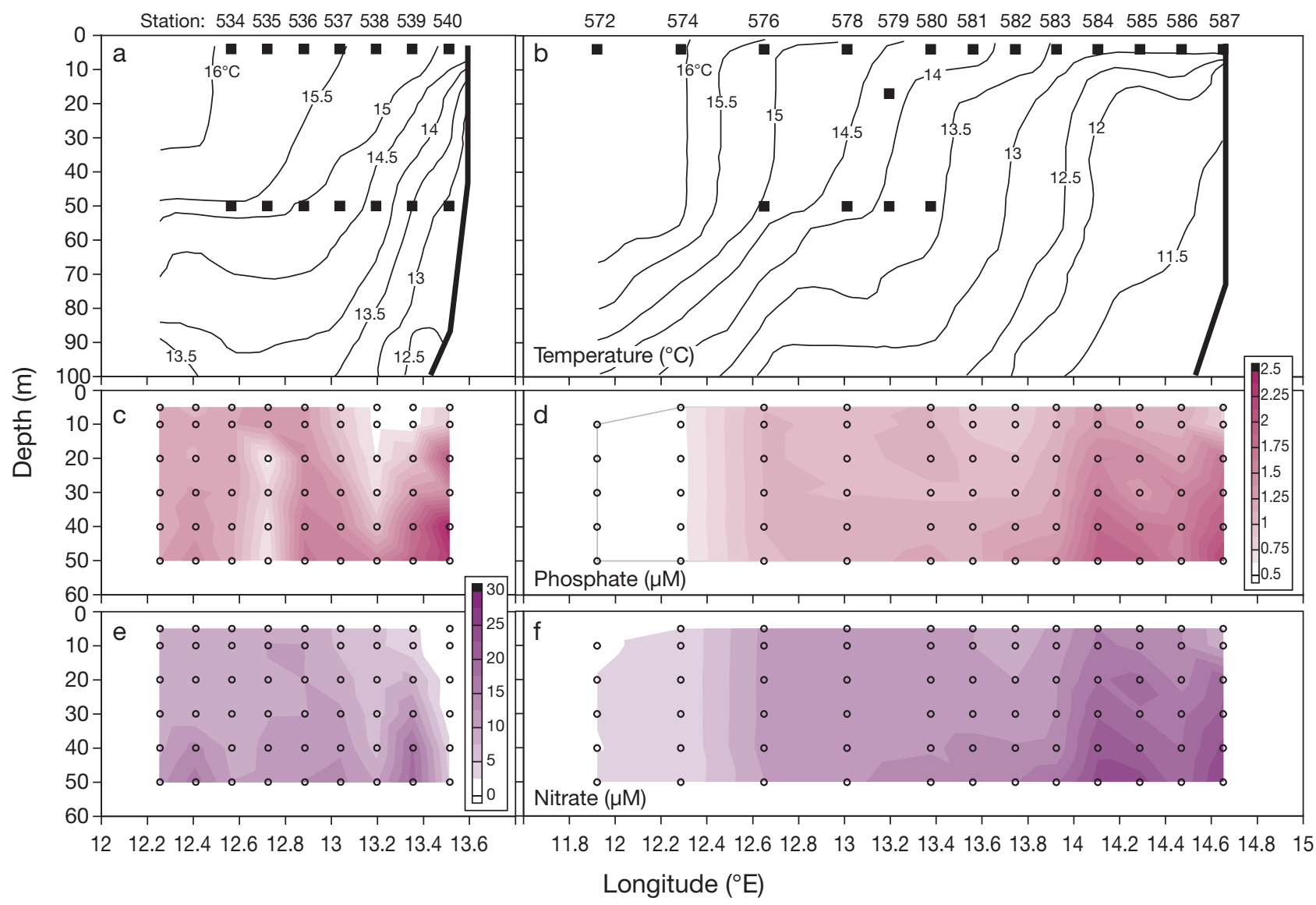

Fig. 2. Sampling stations superimposed on in situ temperature profiles $\left({ }^{\circ} \mathrm{C}\right)$ of the upper $100 \mathrm{~m}$ water column along (a) Transect 3 and (b) Transect 5. Coastal upwelling was most pronounced at the southern Transect 5. (c, d) In situ phosphate ( $\mathrm{PO}_{4}$ ) concentrations $(\mu \mathrm{M})$, and $(\mathrm{e}, \mathrm{f})$ in situ nitrate $\left(\mathrm{NO}_{3}\right)$ concentrations $(\mu \mathrm{M})$ within the upper $50 \mathrm{~m}$ water column along the same transects. 


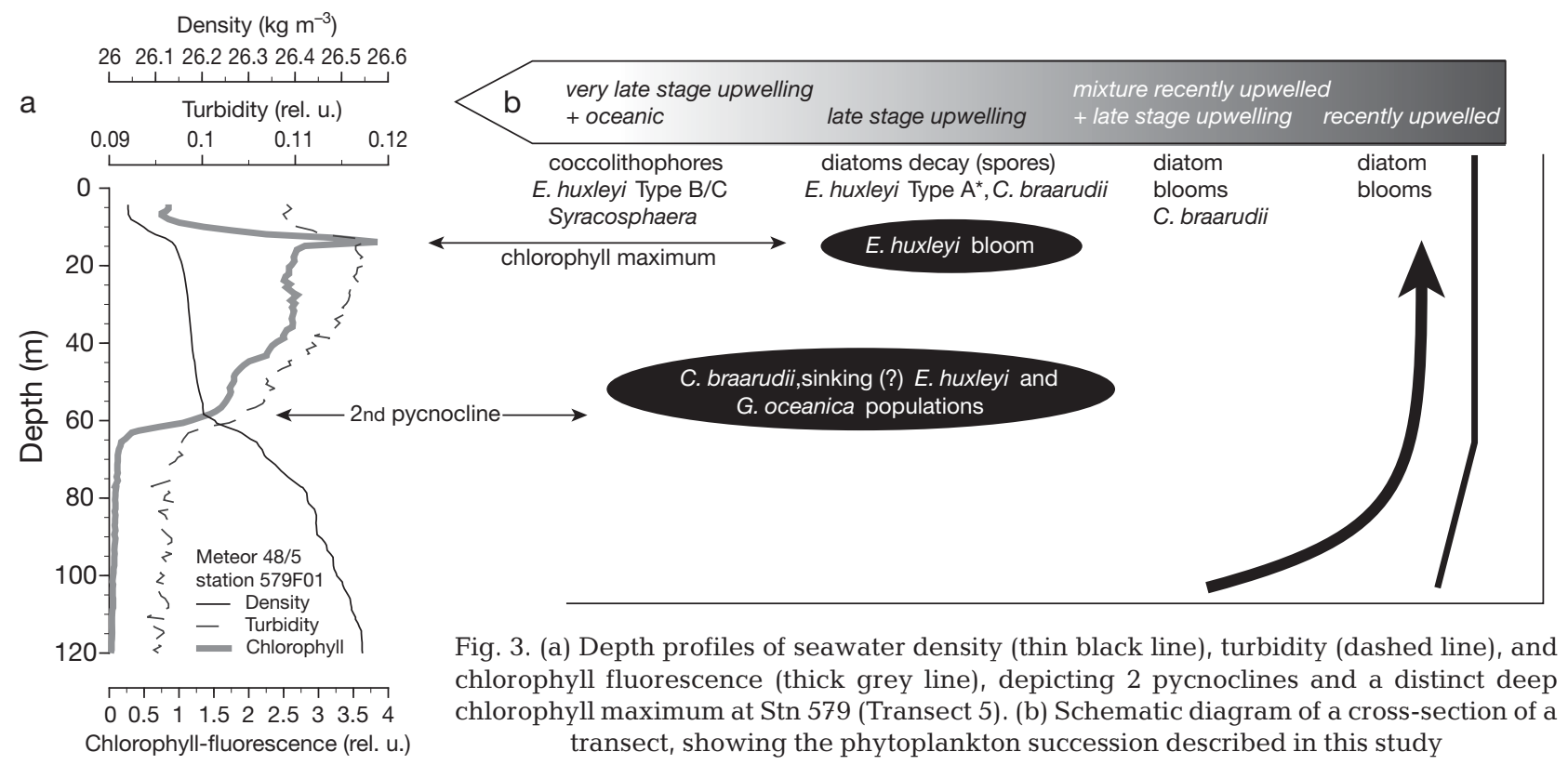

Transect 3
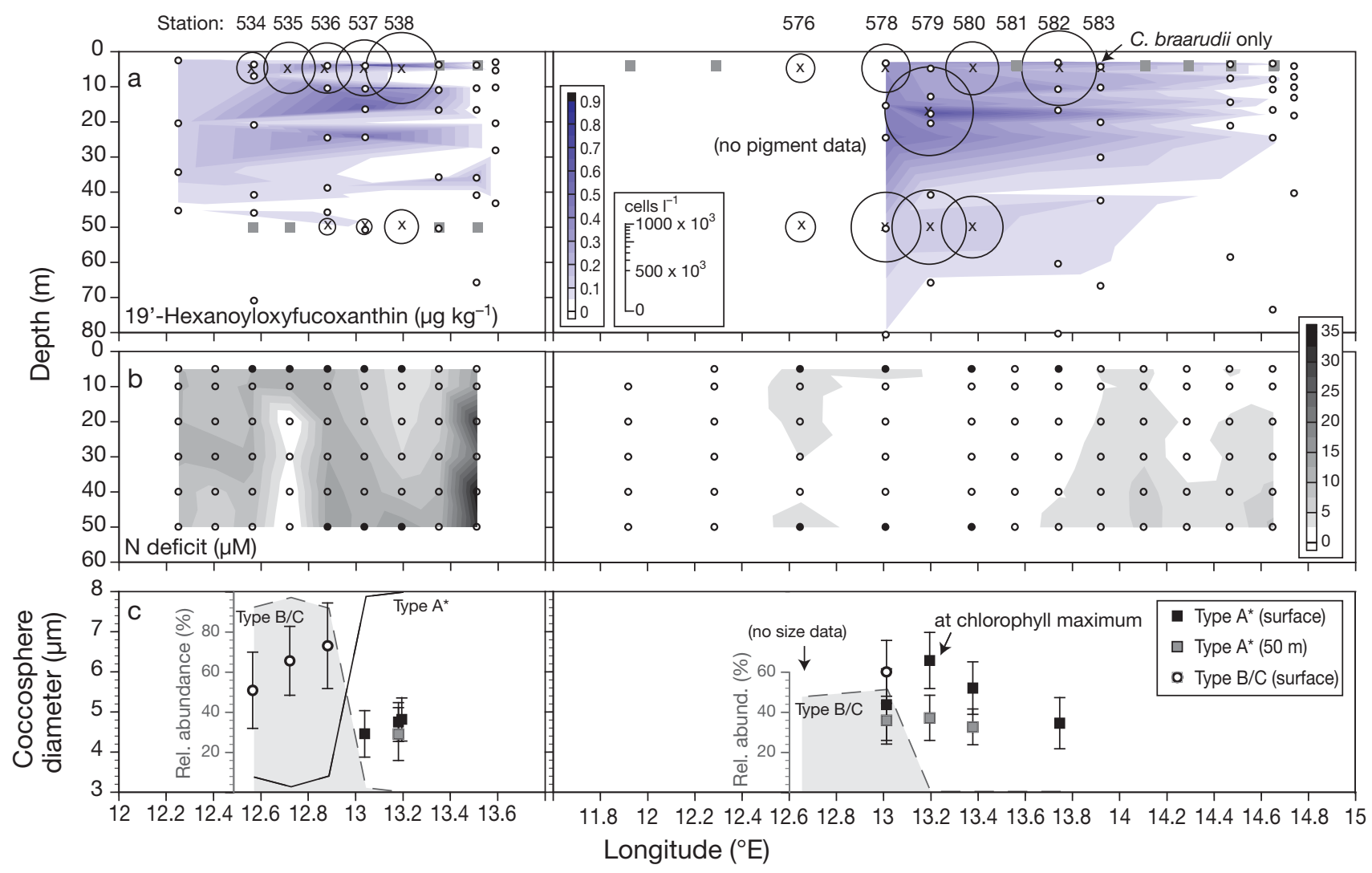

Fig. 4. Emiliania huxleyi. Summary data for Transects 3 and 5. (a) Cell abundance $\left(10^{3}\right.$ cells $1^{-1}$, shown by size of circles according to scale shown in panel for Transect 5; sampling points as crosses) superimposed on in situ concentrations of its marker pigment 19'-HF ( $\mu \mathrm{g} \mathrm{kg}^{-1}$; sampling points as open dots). The highest cell abundance of Type A* was sampled at a 19'-HF maximum (Stn 579, at $\sim 17 \mathrm{~m}$ depth). Grey squares indicate investigated plankton samples that did not contain coccolithophores. (b) Profiles of nitrogen deficit $(\mu \mathrm{M})$, as calculated from in situ nitrate, nitrite, ammonium, and phosphate concentrations. N-deficit is most pronounced along Transect 3, especially at coastal Stn 540 above the shallow shelf. Stations containing E. huxleyi indicated by black dots. (c) Mean coccosphere diameter ( $\left.\mu m_{;} \pm 1 \mathrm{SE}\right)$ of 2 distinct morphotypes, superimposed on their relative abundance (\%; lines, note inset $y$-axis) along Transects 3 and 5. At both transects, Type $\mathrm{A}^{*}$ was the first to succeed coastal diatom blooms. Morphotype B/C was dominant at offshore Stns 534 to 536 on Transect 3 


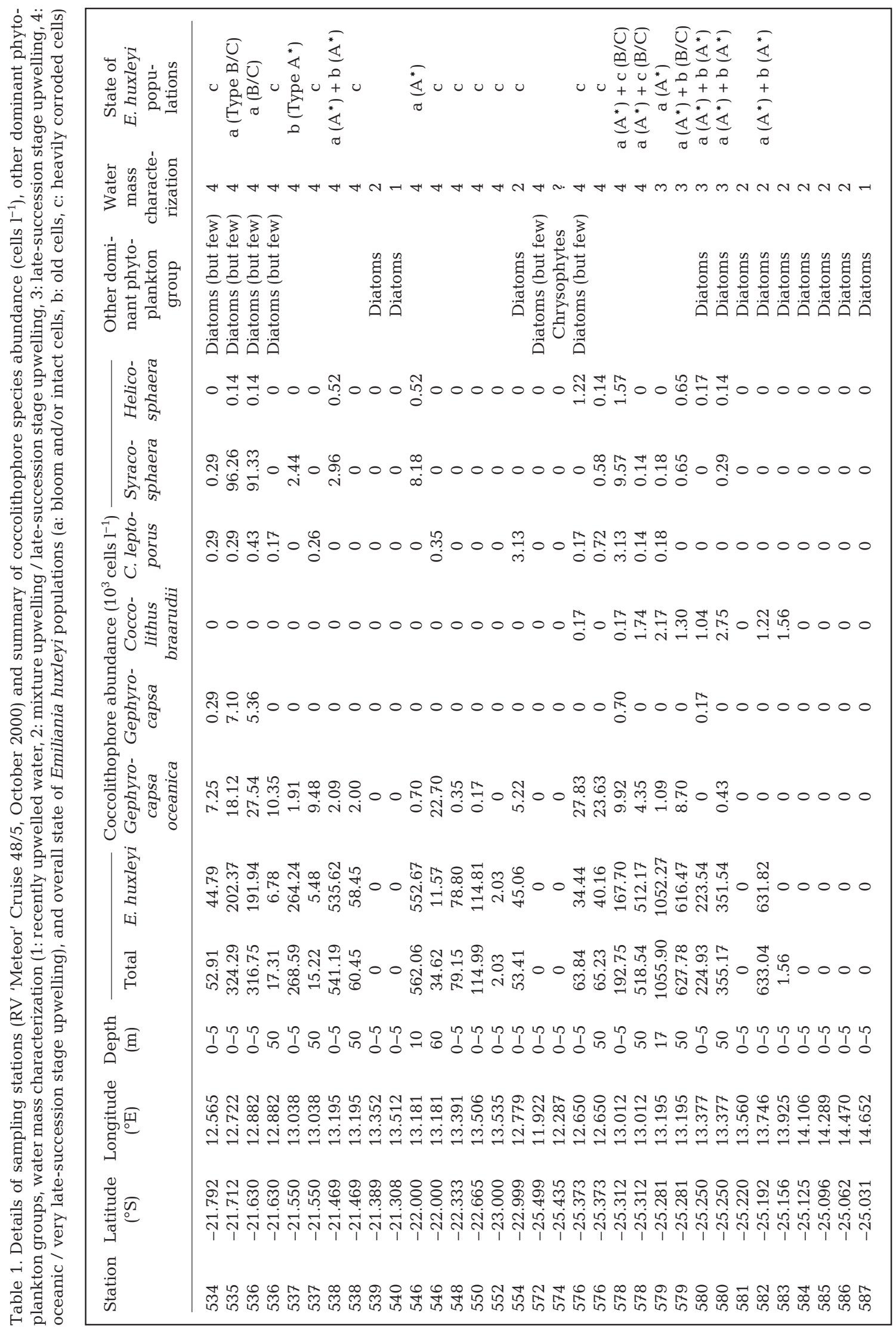


Table 2. Emiliania huxleyi. Summary of the relative abundance and occurrences of 2 dominant morphotypes (Types $A^{*}$ and B/C) as observed within the phytoplankton succession during coastal upwelling off Namibia (October 2000). SST: sea surface temperature. Bull's eye symbols $(\odot)$ denote prominence of a morphotype, open symbols (O) reflect presence of old cells only

\begin{tabular}{|c|c|c|c|c|}
\hline \multirow{2}{*}{$\begin{array}{l}\text { Stations } \\
\text { E. huxleyi }\end{array}$} & \multicolumn{2}{|c|}{ Transect 3 (North) } & \multicolumn{2}{|c|}{ Transect 5 (South) } \\
\hline & $\begin{array}{c}537,538,546 \\
\text { Type A* }\end{array}$ & $\begin{array}{c}\text { 535, } 536 \\
\text { Type B/C }\end{array}$ & $\begin{array}{l}579,580 \\
\text { Type A* }\end{array}$ & $\begin{array}{c}576,578 \\
\text { Type B/C }\end{array}$ \\
\hline Rel. abundance & $98-100 \%$ & $92-97 \%$ & $95-100 \%$ & $49-53 \%$ \\
\hline Chlorophyll max & (not sampled) & & $\odot$ & \\
\hline Shelf edge & $\odot$ & & $\odot$ & \\
\hline Slope & $\odot$ & & $\odot$ & \\
\hline Outer slope & O & $\odot$ & O & O \\
\hline Upwelling & & & $\odot$ & \\
\hline Late succession & $\odot$ & $\odot$ & $\odot$ & 0 \\
\hline Oceanic & & $\odot$ & & 0 \\
\hline $\mathrm{SST}\left({ }^{\circ} \mathrm{C}\right)$ & $14.5-15.4$ & $>15.5$ & $<14.2$ & 15 \\
\hline $\mathrm{N}$ deficit $\left(\mu \mathrm{m} \mathrm{l^{-1 }}\right)$ & $3.5-6.7$ & $>10.8$ & $2.0-2.3$ & $2.7-2.9$ \\
\hline $\mathrm{PO}_{4}\left(\mu \mathrm{m} \mathrm{l}^{-1}\right)$ & $0.6-0.9$ & 1.3 & $0.9-1.1$ & 0.9 \\
\hline $\mathrm{NO}_{3}\left(\mu \mathrm{m} \mathrm{l}{ }^{-1}\right)$ & $5.7-9.5$ & $9.6-9.7$ & $10.8-13.8$ & $10.2-10.6$ \\
\hline $\mathrm{N}: \mathrm{P}$ & $8.2-11.9$ & 7.8 & $13.4-13.9$ & $12.7-13$ \\
\hline Co-occurring with & & $\begin{array}{c}\text { Syraco- } \\
\text { sphaera spp. }\end{array}$ & $\begin{array}{c}\text { Coccolithus } \\
\text { braarudii }\end{array}$ & \\
\hline
\end{tabular}

genetic makeup (cf. Cook et al. 2011). Until further evidence for distinct, heavily calcified upwelling morphotypes is available (see also Beaufort et al. 2008, 2011), we label this Namibian E. huxleyi as Type $\mathrm{A}^{*}$ because it most closely resembles Type A (Young et al. 2003).

A bloom of Emiliania huxleyi Type

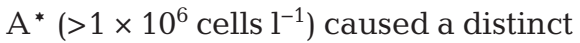
chlorophyll maximum at $17 \mathrm{~m}$ water depth, near a well-developed pycnocline along Transect 5 (Stn 579; Fig. 3), where $\mathrm{PO}_{4}$ concentrations (1 to $1.25 \mu \mathrm{M}$; Fig. 2d) and $\mathrm{NO}_{3}$ levels (10 to $12.5 \mu \mathrm{M}$; Fig. 2f) were moderate and the $\mathrm{N}: \mathrm{P}$ ratio $\approx 13$. Type $\mathrm{A}^{*}$ populations with cell densities up to 0.5 million cells $\mathrm{l}^{-1}$ were also found near a deeper pycnocline at $50 \mathrm{~m}$ water depth, at similar nutrient concentrations and N:P ratios (13 to 14). Farther offshore, the larger but less calcified
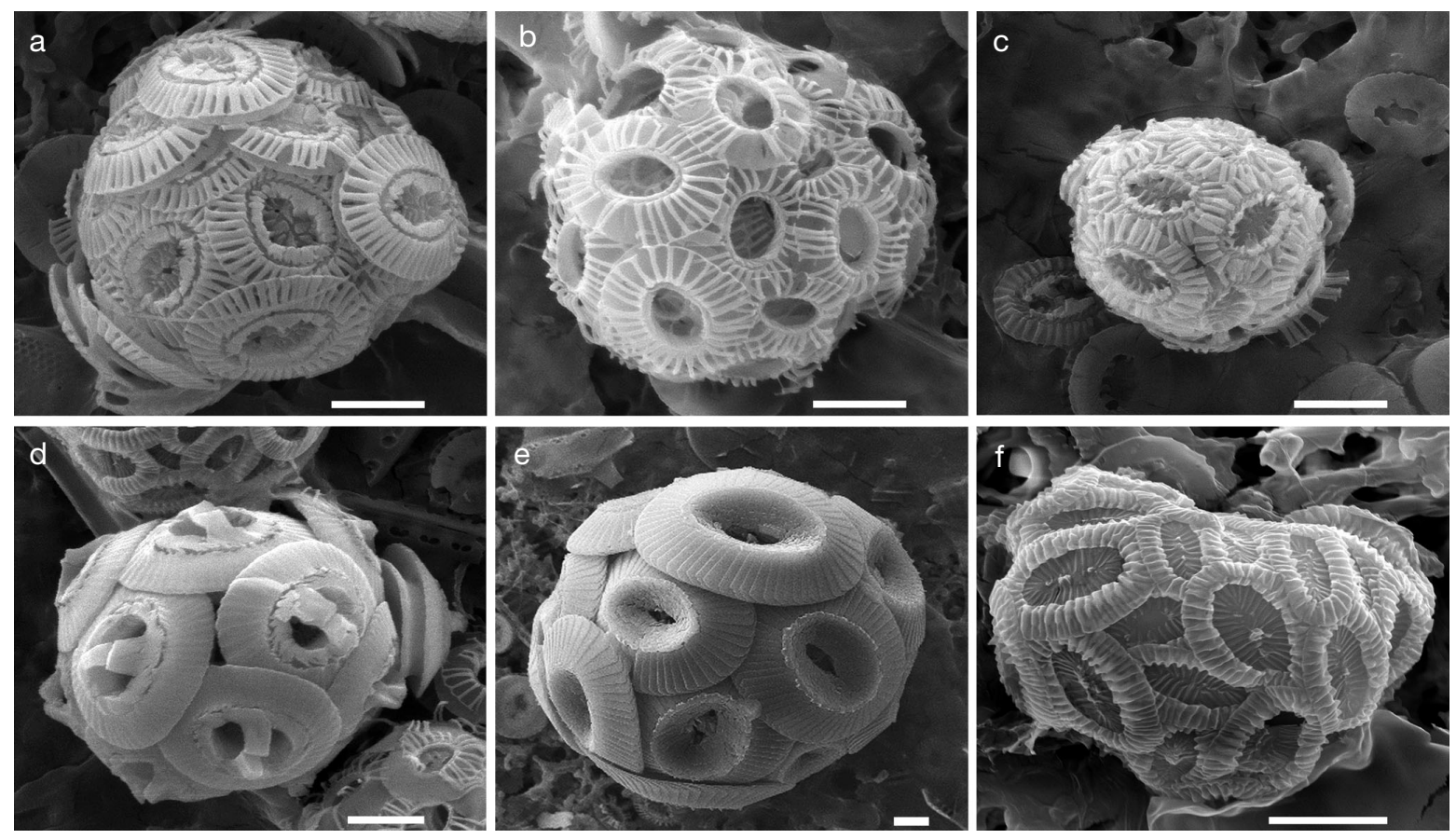

Fig. 5. Emiliania huxleyi. Scanning electron micrographs of morphotypes and other coccolithophore species sampled off Namibia during RV 'Meteor' cruise 48/5, October 2000. Scale bars are $2 \mu \mathrm{m}$. (a) Type A* coccosphere sampled at the chlorophyll maximum (Transect 5, Stn 579, 17 m). (b) Type B/C coccosphere (Transect 3, Stn 536, surface). (c) Type A* coccosphere with distal shield elements 'collapsed' onto proximal shield (Transect 3, Stn 538, surface). (d) Gephyrocapsa oceanica, coccosphere, note 'etched' features surrounding collar (Transect 3, Stn 536, surface). (e) Coccolithus braarudii, coccosphere (Transect 5, Stn 579, $50 \mathrm{~m}$ ). (f) Syracosphaera molischii, coccosphere, slight distortion of normally oval coccoliths may indicate malformation or dissolution (Transect 3, Stn 536, surface) 

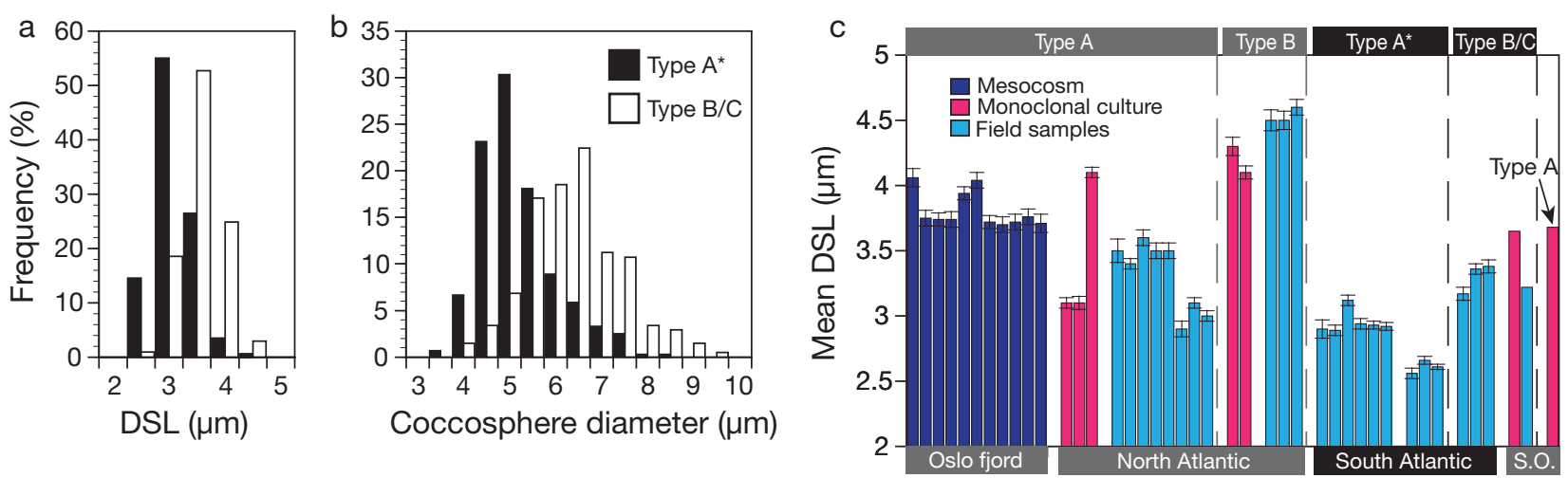

Fig. 6. Emiliania huxleyi. Biometric data. Frequency histograms of (a) coccolith distal shield length (DSL, $\mu \mathrm{m})$ and (b) coccosphere diameter $(\mu \mathrm{m})$ of Type $\mathrm{A}^{*}(\mathrm{~N}=749$ spheres) and Type $\mathrm{B} / \mathrm{C}(\mathrm{N}=205$ spheres) as measured in this study. (c) Variation in mean DSL $(\mu \mathrm{m} \pm 1 \mathrm{SD})$ reported for different morphotypes $\left(\mathrm{A}, \mathrm{B}, \mathrm{A}^{*}, \mathrm{~B} / \mathrm{C}\right)$ in discrete natural populations (mesocosm and plankton studies) and laboratory clones from different regions. Data sources: Oslo fjord: Båtvik et al. (1997); North Atlantic: Young \& Westbroek (1991), van Bleijswijk et al. (1991), South Atlantic: this study; Southern Ocean (S.O.): Cook et al. (2011, who did not report SD, but size ranges for S.O. Type A: $2.89-4.39 \mu \mathrm{m}$; Type B/C: $2.65-4.8 \mu \mathrm{m})$

E. huxleyi Type B/C (cf. Young et al. 2003; Fig. 5b) co-occurred with Type $\mathrm{A}^{*}$ in concentrations of 5500

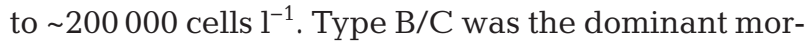
photype (>90\%) at offshore Stns 536 and 535 along Transect 3, where $\mathrm{PO}_{4}$ concentrations were relatively higher (1.25 to $1.5 \mu \mathrm{M}$; Fig. $2 \mathrm{c}$ ) but $\mathrm{NO}_{3}$ levels were lower (7.5 to $10 \mu \mathrm{M}$; Fig. $2 \mathrm{e}$ ), with $\mathrm{N}: \mathrm{P}$ ratios $\approx 8$.

\section{Emiliania huxleyi biometry}

Mean coccosphere diameter ranged between 4.4 and $6.3 \mu \mathrm{m}$ for Type $\mathrm{A}^{*}$, and between 5.5 and $6.6 \mu \mathrm{m}$ for Type B/C, in populations at different stations and sampling depths. Mean coccolith size varied between 2.6 and $3.1 \mu \mathrm{m}$ (Type $\mathrm{A}^{*}$ ) and 3.2 and $3.4 \mu \mathrm{m}$
(Type B/C). Total size ranges revealed significant overlap between both morphotypes (Fig. 6a,b). Coccosphere diameter and coccolith size correlated linearly, although the slope of this regression varied between populations (Fig. 7). The largest coccospheres and coccoliths of Type $\mathrm{A}^{*}$ were sampled at the deep chlorophyll maximum, while populations at the surface and $50 \mathrm{~m}$ water depth were characterized by significantly smaller sphere diameters and lith sizes at both transects (ANOVA, $\mathrm{p}<<0.001$ ). Populations of 250000 to 500000 cells $\mathrm{l}^{-1}$ along Transect 3 had the smallest Type $\mathrm{A}^{*}$ coccospheres and coccoliths, consistently showing signs of 'collapsed' (cf. Young 1994) distal shield elements and etched central tubes, despite distinct overcalcification of the central area (Fig. 5c). Variation in coccolith size of the
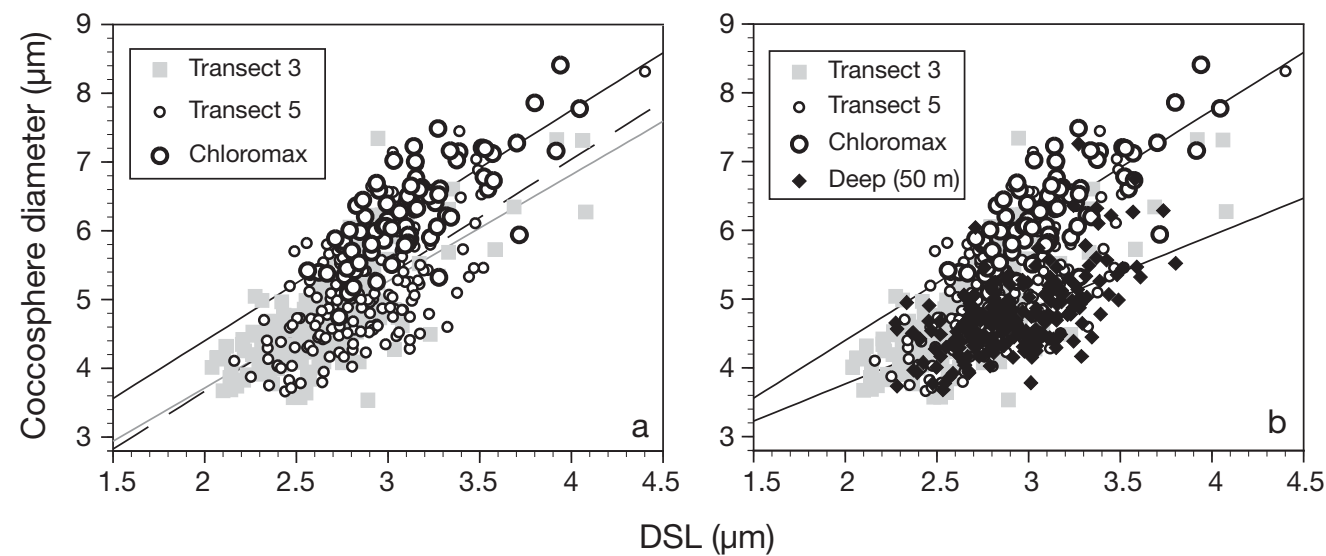

Fig. 7. Emiliania huxleyi. Biometric data of Type A* populations. (a) Linear correlations between coccolith distal shield length (DSL) and coccosphere diameter (both in $\mu \mathrm{m}$ ) in populations sampled along Transect $3(\square)$ and Transect $5(O)$. Coccospheres were largest at the chlorophyll maximum sampled at Stn 579 at $17 \mathrm{~m}$ depth $(O$, solid regression line). (b) As in (a), with overlay of populations sampled at $50 \mathrm{~m}$ depth 
dominant Type $A^{*}$ was statistically similar between the surface and deep samples along Transect 5, but a significant decrease in coccosphere diameter at $50 \mathrm{~m}$ (ANOVA, p $<<0.001$ ) could relate to physiological changes at this depth, or may be indicative of old cells. Several stations, most notably those south of Transect 3 (548,550,552, and 554), rendered lower cell counts and damaged or corroded E. huxleyi cells, an indication of decaying populations (Table 1).

\section{Other coccolithophore species}

Coccolithophore species diversity increased offshore and included Gephyrocapsa oceanica, G. muellerae, and $G$. ericsonii (the latter 2 were rare and are grouped as Gephyrocapsa spp. in Table 1). G. oceanica ranged from a few hundred to $>27000$ cells $1^{-1}$ and was present both at the surface and $50 \mathrm{~m}$ depth. However, many of the G. oceanica coccospheres showed signs of secondary corrosion with etched central tube elements (Fig. 5d). Coccolithus braarudii was observed in late-stage upwelling waters along Transect 5 (1000 to 2800 cells $~^{-1}$ ) at the surface and $50 \mathrm{~m}$ water depth. This species showed no signs of secondary corrosion and/or malformation in any of the samples (Fig. 5e). It was the only coccolithophore species present at Stn 583, where it co-existed with diatoms and zooplankton (copepod nauplia; Fig. 4a). Syracosphaera spp. (mostly S. molischii, Fig. 5f; but also including $S$. epigrosa and $S$. pulchra) were the second largest contributors to the assemblage at Stns 535 and 536 (Transect 3) where their cell abundances reached $>90000$ cells $l^{-1}$.

\section{Multivariate statistical analysis}

Principal component analysis of environmental parameters obtained from a total of 33 samples revealed distinct regional gradients in physical ocean properties, related to coastal upwelling and nutrient balance. In this statistical analysis, we excluded all derived environmental variables, such as N:P or N-deficit, as well as (indirect) measures of biomass, such as turbidity, oxygen, and chl a concentrations. The first would introduce redundant variables, whereas we wanted to test how various biomass-related variables correlate to physical ocean properties. Measurements of $\mathrm{NH}_{4}$, which showed negative correlations with $\mathrm{N}$-deficit $(\mathrm{r}=-0.60, \mathrm{p}=0.003$ ) and phosphate concentrations $(r=-0.53, p=0.009)$, were excluded because of missing values at 10 out of 33 stations.

Two principal components (PCs) explained about $73 \%$ of total variance in environmental parameters (Table 3). The first principal component (PC1) exhibited positive loadings on seawater density and nitrate concentrations, and negative loadings on temperature and salinity, explaining $\sim 48 \%$ of total variance. Sample scores on PC1 were strongly correlated with longitude $(\mathrm{r}=0.87, \mathrm{p}<<0.001)$, and thus distance from shore. We interpret PC1 to represent the gradient between coastal upwelling of cool, dense waters closest to shore and warmer oceanic waters farther offshore.

The second principal component (PC2) had a strong positive loading on phosphate concentrations, explaining another $\sim 25 \%$ of the total variance. At increased $\mathrm{PO}_{4}$ levels, the balance of major nutrient showed trends towards nitrogen-limiting conditions. Indeed, sample scores on PC2 held the strongest correlation with the calculated $\mathrm{N}$-deficit $(\mathrm{r}=0.71, \mathrm{p}=0)$, and were inversely correlated to turbidity $(\mathrm{r}=-0.54$, $\mathrm{p}=0.001)$ and oxygen concentrations $(\mathrm{r}=-0.53, \mathrm{p}=$ 0.002). Chl a concentrations also showed an inverse

Table 3. Loadings of environmental parameters selected in our principle component analysis (PCA), and additional Pearson correlation coefficients $(\mathrm{r})$ for relationships between other variables and PCA factors $(\mathrm{N}=33)$ and mean biometry results for morphotype $A^{*}(N=9)$. DSL: distal shield length. $r$-values in bold are significant at $\mathrm{p}<0.005,{ }^{*} \mathrm{p}<0.01,{ }^{* *} \mathrm{p}<0.05$

\begin{tabular}{|c|c|c|c|c|}
\hline & \multicolumn{2}{|c|}{ PCA results } & \multirow{2}{*}{\multicolumn{2}{|c|}{$\begin{array}{l}\text { Biometry mean } \\
\text { results (Type A*) }\end{array}$}} \\
\hline & \multirow[t]{2}{*}{$\mathrm{PC} 1$} & \multirow[t]{2}{*}{ PC2 } & & \\
\hline & & & $\begin{array}{l}\text { Coccolith } \\
\text { DSL }\end{array}$ & $\begin{array}{l}\text { Cocco- } \\
\text { sphere }\end{array}$ \\
\hline PC1 & 1 & & $0.73^{* *}$ & 0.47 \\
\hline $\mathrm{PC} 2$ & 0 & 1 & 0.28 & -0.13 \\
\hline \multicolumn{5}{|c|}{ Environmental factor loadings: } \\
\hline Density & 0.85 & 0.49 & $0.73^{* *}$ & 0.16 \\
\hline $\mathrm{SST}$ & -0.98 & -0.14 & $-0.84^{*}$ & -0.35 \\
\hline Salinity & -0.90 & 0.32 & -0.91 & -0.61 \\
\hline $\mathrm{SiO}_{2}$ & -0.14 & 0.16 & -0.90 & -0.62 \\
\hline $\mathrm{NO}_{2}$ & 0.13 & 0.06 & 0.80 & 0.42 \\
\hline $\mathrm{NO}_{3}$ & $0.47^{*}$ & 0.56 & 0.72 & 0.17 \\
\hline $\mathrm{PO}_{4}$ & 0.01 & 0.97 & 0.46 & -0.07 \\
\hline \multicolumn{5}{|l|}{ Other variables: } \\
\hline $\mathrm{N}: \mathrm{P}$ & 0.32 & $-0.45^{*}$ & $0.83^{*}$ & 0.43 \\
\hline N-deficit & -0.38 & 0.71 & $-0.79^{* *}$ & -0.48 \\
\hline Latitude (South) & $-0.45^{*}$ & 0.39 & -0.91 & -0.48 \\
\hline Longitude (East) & 0.87 & -0.02 & 0.28 & 0.22 \\
\hline Sample depth_CTD & 0.07 & 0.63 & 0.41 & -0.25 \\
\hline Turbidity & $0.47^{*}$ & -0.54 & 0.51 & $0.78^{* *}$ \\
\hline Oxygen & 0.38 & -0.53 & 0.88 & $0.72^{* *}$ \\
\hline \multirow[t]{2}{*}{ Chlorophyll a } & $0.41^{* *}$ & -0.32 & $-0.73^{* *}$ & -0.21 \\
\hline & $\mathrm{N}=33$ & $\mathrm{~N}=33$ & $\mathrm{~N}=9$ & $\mathrm{~N}=9$ \\
\hline
\end{tabular}




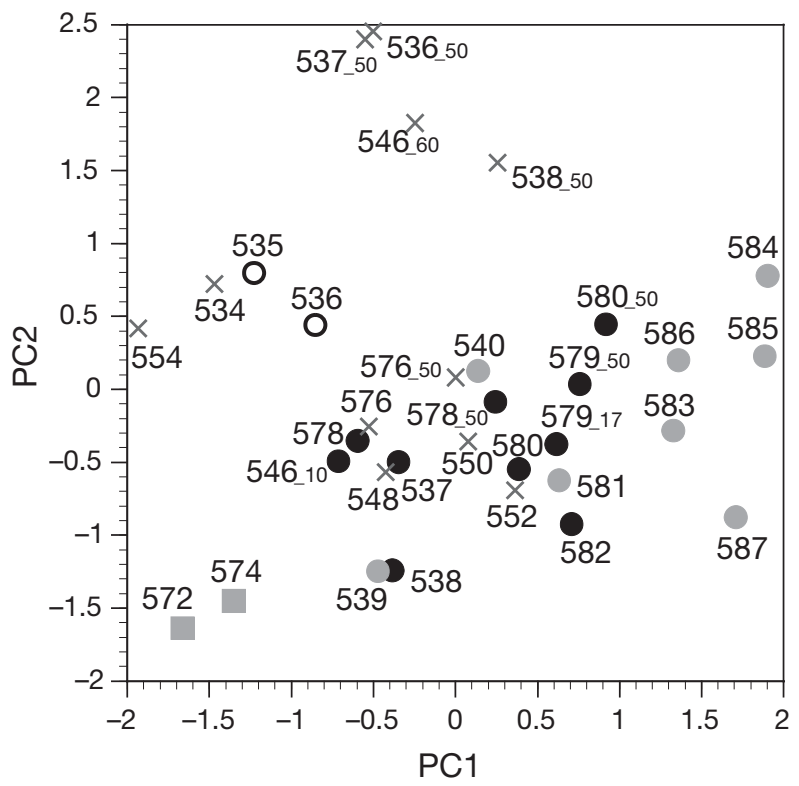

Fig. 8. Sample scores on the first 2 principal components (PCs), which together explain $75 \%$ of the total variance in physical oceanographic parameters. PC1 reflects the gradient between coastal upwelling (positive scores) and oceanic conditions farther offshore (negative scores). Positive scores on $\mathrm{PC} 2$ reflect higher $\mathrm{PO}_{4}$ concentrations and a larger Ndeficit. Stations (and their depth if not at surface) are indicated and classified based on general characteristics of the sampled phytoplankton communities: coastal diatom blooms (๑), Emiliania huxleyi Type A* (०), E. huxleyi Type B/C (O), old cells of E. huxleyi (×), oceanic diatoms ( $\square)$

relationship with $\mathrm{PC} 2$, but this was not significant at $\mathrm{p}<0.05(\mathrm{r}=-0.32, \mathrm{p}=0.067)$.

In general, seawater turbidity was highest at stations influenced by upwelling and where in situ nutrients were highest and closest to the Redfield ratio $(\mathrm{N}: \mathrm{P}=16)$, and lowest under increased nitrogen deficiency. Local maxima in turbidity corresponded to blooms of either coccolithophores or diatoms. Turbidity and coccolithophore standing stocks were lowest along the northern Transect 3, at $50 \mathrm{~m}$ water depth, where the largest $\mathrm{N}$-deficit was recorded. PC2 is therefore interpreted in terms of nutrient concentrations and its relation to phytoplankton biomass. Positive scores on PC2 reflect increased fixed-nitrogen depletion, whilst negative scores imply a higher nutrient levels and a nutrient balance closer to the Redfield ratio. Fig. 8 depicts groupings of the investigated samples in relation to PC1 and PC2. Transect 5 covered the widest range of conditions along $\mathrm{PC} 1$, from intense coastal upwelling to oceanic settings, with relatively well-balanced in situ nutrients. Transect 3 covered a larger gradient in nutrient conditions and included samples with high $\mathrm{N}$-deficit.

\section{DISCUSSION}

\section{Phytoplankton succession and Emiliania huxleyi morphotypes}

This study documents the dynamic phytoplankton successions that took place within the time span of a few days during active coastal upwelling offshore Namibia in October 2000 (Fig. 3b). High frequency variations in phytoplankton species composition and biomass are typical of upwelling areas (e.g. Pitcher et al. 1991, Aguilera et al. 2009). The highest biomass of diatoms that we found occurred closest to shore in recently upwelled waters. Blooms of the coccolithophore Emiliania huxleyi prevailed in mature upwelled waters, while farther offshore in oceanic surface waters, biomass decreased and coccolithophore diversity increased. Both studied transects revealed similar phytoplankton successions, but the southern Transect 5 recorded higher biomass and $\mathrm{N}$ :P ratios, confirming ship-board measurements that this was a region of more intense upwelling.

Emiliania huxleyi was the most abundant coccolithophore in nearly all of our counts. Previous work in the region had also reported on extensive blooms of this species (e.g. Mitchell-Innes \& Winter 1987, Siegel et al. 2007). Here, we document for the first time the occurrence of 2 distinct E. huxleyi morphotypes within this succession of phytoplankton 'booms' and 'busts.'

The more heavily calcified Type $A^{*}$ was the first to succeed coastal diatom blooms at both investigated transects. Type $A^{*}$ bloomed both at the surface and at deeper levels of the euphotic zone, causing a distinct chlorophyll maximum at $\sim 17 \mathrm{~m}$ (sampled at Stn 579, Transect 5; Figs. $3 \& 4$ a), where it also produced the largest coccoliths and coccospheres (double layers of coccoliths). Compared to the chlorophyll maximum station, Type $A^{*}$ coccospheres were significantly smaller in populations encountered at the surface and $50 \mathrm{~m}$ water depth, but still prevailed at

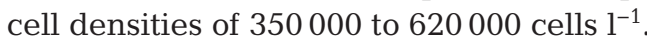

By contrast, morphotype B/C, characterized by more delicate coccoliths with an open or 'plated' central area, was most abundant in very late-stage upwelling or oceanic (not influenced by upwelling) surface waters along Transect 3, at $\sim 200000$ cells $1^{-1}$. Type B/C co-occurred with few Type $\mathrm{A}^{*}$ cells and other coccolithophore species, most notably Syracosphaera spp., in N-deficient waters. Interestingly, coccoliths of a more delicately calcified variety were observed in situ during an upwelling season in March/April 2003 in a location very similar to ours 
(Siegel et al. 2007). These authors described Emiliania huxleyi 'Type $C$ ' with a coccolith size of 'approximately $3.3 \mu \mathrm{m}$ ' that is similar to the dimensions we report here for Type B/C. It is possible that their samples were misidentified (we cannot tell because the SEM images in their Fig. 5 are of low resolution and without scale bars) or that the 2003 upwelling regime was different, as each upwelling regime has its own particular physical and chemical oceanographic characteristics. SeaWIFS satellite images (Siegel et al. 2007) suggest that the 'Type $C$ ' bloom in 2003 originated offshore and remained restricted to the outer edge of the shelf and above the slope, and may have been located beyond the local upwelling front. Siegel et al. (2007) also noted a chlorophyll maximum at $\sim 19 \mathrm{~m}$ along 1 of their studied transects, but had no in situ samples verifying the presence of $E$. huxleyi at this depth. Our results confirm the presence of E. huxleyi Type $\mathrm{A}^{*}$ at $17 \mathrm{~m}$ and at $50 \mathrm{~m}$, and reveal that these populations are associated with distinct pycnoclines at these depths. Such large numbers of coccolithophores observed at depths in the deeper euphotic zone are beyond the reach of satellites, and therefore coccolithophore calcification and primary productivity in upwelling areas may be strongly underestimated if determined by satellite observations alone.

\section{Environmental controls on Emiliania huxleyi morphotypes}

Few studies have identified possible environmental controls (e.g. temperature, salinity, nutrient levels, and seawater carbonate chemistry) on the occurrence and abundance of Emiliania huxleyi morphotypes. Different E. huxleyi morphotypes have been shown to occur across oceanic fronts on a much larger spatial scale than we report here for the Benguela region. In the Australian sector of the Southern Ocean, the distribution of 2 dominant morphotypes (Types A and B/C) appears strongly determined by environmental gradients across the Subtropical and Subantarctic Fronts (Findlay \& Giraudeau 2000, Cubillos et al. 2007). Similarly, Type A and Type B/C occupied distinct water masses offshore Japan, where they were labeled as, respectively, 'warm-water' and 'cold-water' types (Hagino et al. 2005). The Benguela system happens to straddle an SST interval where different morphotypes commonly (co-)occur, close to an apparent upper temperature tolerance of $\sim 15^{\circ} \mathrm{C}$ for Type B/C (Findlay \& Giraudeau 2000, Hagino et al. 2005). Our study indicates that $E$. huxleyi morphotypes in the Benguela upwelling region may be dependent on oceanographic conditions as identified by principal component analysis. Type $\mathrm{A}^{*}$ had the highest cell concentrations in late-stage upwelling waters (PC1) with relatively balanced nutrient concentrations (PC2) at in situ N:P = 13 to 14 , whereas Type B/C was dominant in oceanic surface waters with higher phosphate concentrations and significant nitrogen deficiency ( $\mathrm{N}: \mathrm{P} \sim 8$; Table 2, Fig. 9a). Coccolithophore blooms are known to drastically affect nutrient concentrations and their balance (e.g. Engel et al. 2005), and it is important to note that the in situ nutrients and $\mathrm{N}: \mathrm{P}$ values are not necessarily the same as the nutrient conditions that triggered the occurrence of the sampled coccolithophore populations. Siegel et al. (2007) argued that the bloom of 'Type C' in March 2003 developed in P-limited waters, but that the in situ N:P ratio of the bloom was subsequently drastically lowered to 8.9. However, our data do not lend support to P-limiting conditions under any stage of the upwelling succession sampled along Transects 3 and 5.

Another environmental parameter to consider is light. Irradiance appears to be a central factor in determining the occurrence of Emiliania huxleyi blooms, which rarely occur beyond water depths of $20 \mathrm{~m}$ (Zondervan 2007 and references therein). High turbidity leads to lower irradiance, but Type $\mathrm{A}^{*}$ seems to cope very well under these conditions at the chlorophyll maximum at $17 \mathrm{~m}$ depth. The occurrence of the same morphotype at $50 \mathrm{~m}$ depth, with up to

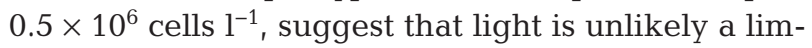
iting factor. However, light levels may drastically affect the calcification to photosynthesis ratio (Balch et al. 1996, Zondervan 2007) and could thus in part explain variability in coccosphere diameter and coccolith size of the sampled populations (Fig. 7; see discussion below).

Ocean $\mathrm{pH}$ is another possible environmental control of coccolithophore morphotypes (Cubillos et al. 2007, Beaufort et al. 2011). Cubillos et al. (2007) demonstrated a shift in 'calcification' types of Emiliania huxleyi in the Southern Ocean and argued that such morphotype replacement could be due to changing carbonate chemistry (ocean acidification). It is well known that upwelling regions also experience strong gradients in dissolved inorganic carbon (DIC) and $\mathrm{pH}$. The upwelling of deep, more corrosive waters with high DIC and low $\mathrm{pH}$ (see e.g. datasets for WOCE Section A10 from 1998 and CLIVAR A10repeat from 2003: Carbon Dioxide Information Analysis Center, http://cdiac.ornl.gov/oceans/woce 


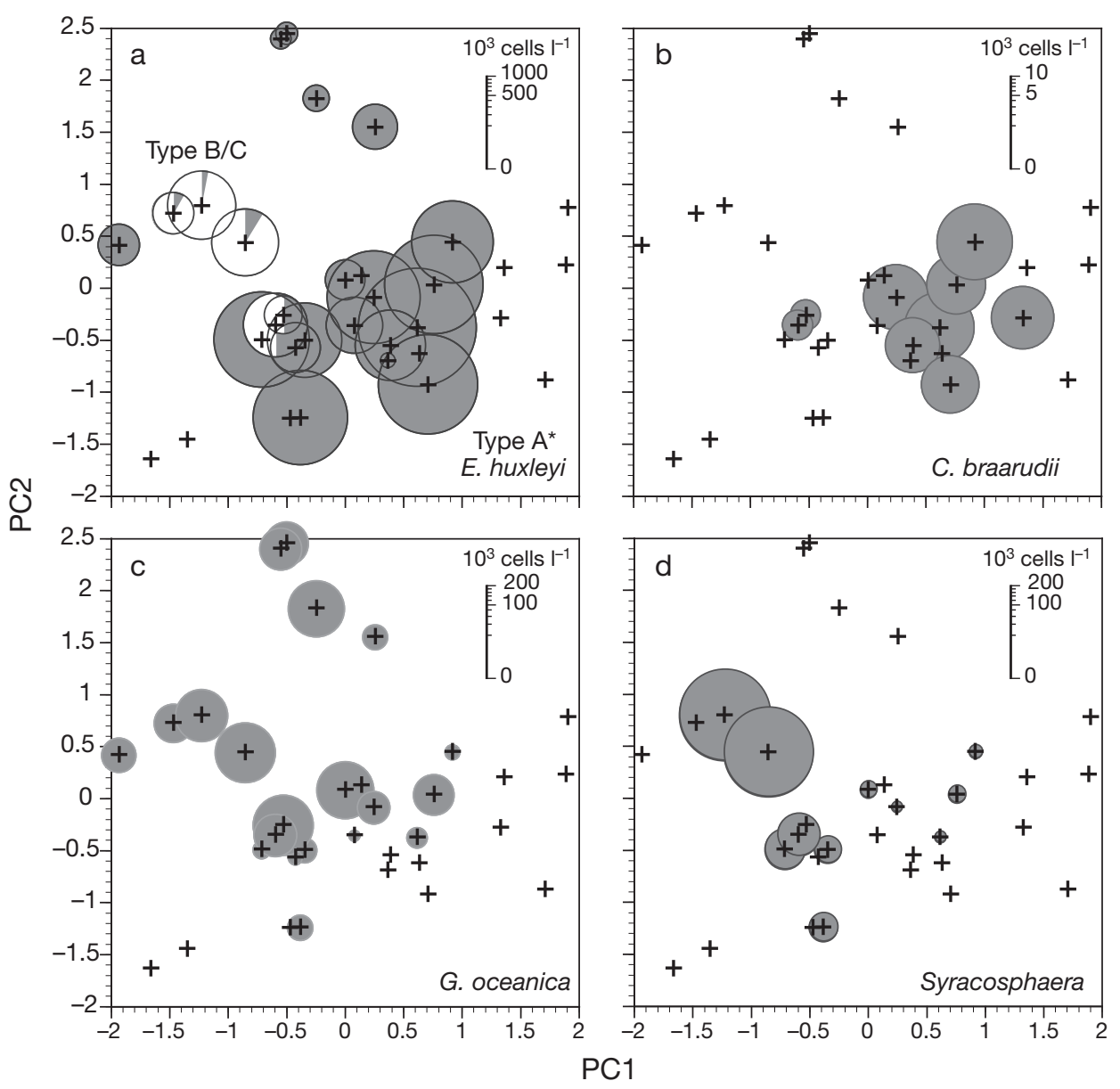

Fig. 9. Sample scores on the first 2 principal components, with overlay of coccolithophore cell abundance $\left(10^{3}\right.$ cells $\left.1^{-1}\right)$ of $(\mathrm{a})$ Emiliania huxleyi, Type

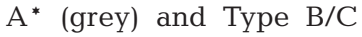
(white), (b) Coccolithus braarudii, (c) Gephyrocapsa oceanica, and (d) Syracosphaera spp. (see also Fig. 5) a10.html) and subsequent activity of phytoplankton blooms (uptake of DIC) can lead to highly variable carbonate chemistry of the surface waters (e.g. Astor et al. 2005, Santana-Casiano et al. 2009).

Unfortunately, no in situ measurements of carbonate chemistry or ocean $\mathrm{pH}$ were performed during the sampling campaign in October 2000. However, observation of Emiliania huxleyi coccolith morphology indicates that more corrosive conditions may persist in mature upwelling waters. Despite being relatively heavily calcified, E. huxleyi Type A* displays a very consistent gap between the distal shield elements and inner tube elements (Fig. 5a), some populations showing distal shield elements 'collapsed' onto the proximal shield. Young (1994) interpreted this as a secondary, early dissolution effect, causing the loss of continuity between proximal and distal elements due to the etching of tube elements. We did not observe this type of etching in Type B/C that was the dominant morphotype at non-upwellinginfluenced stations. In an earlier study off Namibia, Giraudeau et al. (1993) described similar morphologies in Gephyrocapsa oceanica and Coccolithus braarudii as coccolith malformation, arguing against secondary dissolution because of carbonate supersaturation at the time of sampling (during upwelling in March 1992, see Fig. 1). We also observed similar 'etched' tubes in Gephyrocapsa spp., but not in $C$. braarudii. Curiously, this feature has only been described in plankton samples (see also Kleijne 1990), never in coccoliths found in the sediments (where dissolution tends to affect the distal shield elements of $E$. huxleyi and G. oceanica first).

Culture experiments have shown that different strains of Emiliania huxleyi respond differently to elevated levels of $\mathrm{CO}_{2}$ and decreased $\mathrm{pH}$ in seawater (e.g. Riebesell et al. 2000, Iglesias-Rodríguez et al. 2008). Strain-specific calcification and growth rate responses do not appear to be influenced by the morphotype, but are likely genetic in origin (Langer et al. 2009). This complexity of genotype-specific responses highlights a heterogeneity in physiology and adaptive strategies within the species E. huxleyi. Most laboratory experiments have been conducted to unravel relationships between physiology and individual environmental parameters on single strains. Field sampling of natural populations, most likely composed of multiple genotypes (e.g. Iglesias- 
Rodríguez et al. 2006) and morphotypes (e.g. Hagino et al. 2005, Beaufort et al. 2011, this study), is crucial to provide us with a more detailed understanding of the ecophysiological plasticity within this 'cosmopolitan' species and improve our process-oriented understanding of climatic adaptation by coccolithophores.

\section{Emiliania huxleyi biometry: morphotypes and physiological state}

Mean coccolith size has been used to distinguish among Emiliania huxleyi morphotypes (Fig. 6). Because of significant overlap in overall size ranges between different morphotypes, it is important to record other morphological characteristics, such as degree of calcification of the central area and morphology of distal shield elements.

Sampling through a plankton succession also implies that the phytoplankton populations are sampled at different life stages and thus physiological states. Before, during, and after a bloom, coccolithophores experience exponential growth, stationary growth, and subsequent decay (cell death), which is known to affect coccolith and coccosphere size under controlled growth experiments (e.g. Young \& Westbroek 1991, Båtvik et al. 1997, Engel et al. 2005). A change in mean coccolith and coccosphere size within the sampled Benguela populations could thus be due to several reasons: (1) a shift in morphotypes of different size (in our case a shift from smaller Type $\mathrm{A}^{*}$ to larger Type B/C), (2) phenotypic plasticity under different environmental conditions (e.g. Type $A^{*}$ populations at Transect 5 versus Transect 3), and/or (3) different growth stage of the same morphotype (e.g. Type $\mathrm{A}^{*}$ at chlorophyll maximum versus $50 \mathrm{~m}$ depth).

We cannot distinguish between scenarios (2) and (3) without detailed knowledge of in situ growth rates. However, the available data for Type A*, although admittedly representing a borderline sample size ( $N=9$, excluding populations with old cells), do reveal correlations between intra-type variability in mean coccolith size and upwelling stage $(\mathrm{PC} 1 ; \mathrm{r}=$ $0.73, p=0.027$ ) and a range of other parameters (see Table 3), including nutrient balance (N:P; $\mathrm{r}=0.83, \mathrm{p}=$ $0.006)$, nitrite $\left(\mathrm{NO}_{2} ; \mathrm{r}=0.80, \mathrm{p}=0.01\right)$, and an inverse relationship to silicate concentrations $\left(\mathrm{SiO}_{2} ; \mathrm{r}=-0.90\right.$, $\mathrm{p}=0.001)$. The strong correlation with latitude $(\mathrm{r}=$ $-0.91, p=0.001$ ) reflects the size differences between Transects 3 and 5, already highlighted by ANOVA. Statistically significant linear relationships also exist between mean coccosphere diameter of Type $\mathrm{A}^{*}$ and turbidity $(\mathrm{r}=0.78, \mathrm{p}=0.014)$, as well as oxygen concentrations $(r=0.72, p=0.029)$. Large and heavy coccoliths and coccospheres have also been reported for regions with relatively high fertility in the Marquises Island and in the Peru-Chile upwelling regions (Beaufort et al. 2008).

We hypothesize that the high cell numbers and large (double-layered) coccospheres of Type $\mathrm{A}^{*}$, at the chlorophyll maximum, may reflect late-stage bloom conditions (late-stage exponential growth or onset of stationary growth), consistent with observations in culture experiments. Young \& Westbroek (1991) recorded 'abnormally large' coccoliths of Type A under late stationary growth phase, while Engel et al. (2005) reported on heavier coccoliths (larger and/or thicker) produced during late-stage exponential growth and early post-bloom conditions in mesocosm experiments. On the other hand, populations at $50 \mathrm{~m}$ depth along Transect 5 were clear outliers in terms of coccosphere/coccolith proportions (Fig. 6b), and may be indicative of growth-limiting (perhaps low light) conditions at this depth or even cell shrinkage within a decaying bloom. Pigment content would be expected to decrease as the cells decline and decay, which seems to be corroborated by the low in situ 19'-HF concentrations measured at $50 \mathrm{~m}$ depth, as well as other stations containing 'heavily corroded cells' (Table 1, Fig. 10). Coccolith production (calcification rate) is significantly less light-dependent than photosynthesis, so that the

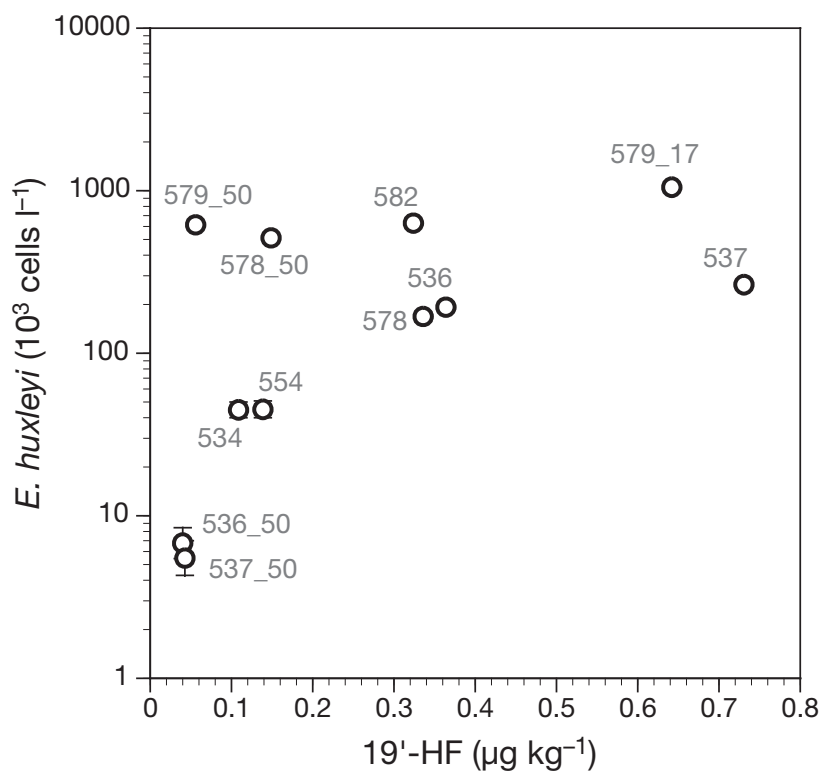

Fig. 10. Emiliania huxleyi. Comparison of cell abundance $\left(10^{3}\right.$ cells $\mathrm{l}^{-1}$, note log scale) and in situ concentrations of its marker pigment, $19^{\prime}$-HF $\left(\mu \mathrm{g} \mathrm{kg}^{-1}\right)$, at corresponding stations 
ratio between these processes (C:P) increases deeper in the euphotic zone (Balch et al. 1992), but should again decline when light becomes even more limiting (Zondervan 2007). Clearly, more data will be needed to better constrain these tentative biometric patterns for various morphotypes, in both culture and field samples, before we can conclude on their physiological implications.

\section{Other coccolithophores}

Emiliania huxleyi was not the only prominent coccolithophore in this area. Although not a domi-

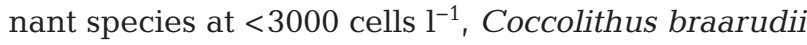
appears to be a key indicator for the late-stage upwelling waters sampled along Transect 5 (Fig. 9b). Gephyrocapsa oceanica was a constant contributor to the coccolithophore assemblages, with comparable cell densities at both transects, despite significant differences in nutrient conditions (Fig. 9c). Syracosphaera spp. were most abundant at Stns 535 and 536 (Transect 3; Fig. 9d), co-existing with E. huxleyi Type B/C and other coccolithophores. S. epigrosa was also dominant in regions where upwelling and oceanic waters mixed during a period of active upwelling in late June 1993 (Giraudeau \& Bailey 1995). A coccolithophore bloom dominated by S. pulchra (at $>10$-fold the cell densities observed in this study) was recorded by satellite and in situ verification from end of March to beginning May 2003, following a period of moderate upwelling and associated with warm water $\left(16^{\circ} \mathrm{C}\right)$ on the seaward edge of the upwelling front (Weeks et al. 2004).

\section{CONCLUDING REMARKS}

The globally successful Emiliania huxleyi is among the most adaptive species of all modern coccolithophores. One strategy to understand its competitive edge is to consider the regional dynamics of natural populations, which typically encompass multiple genotypes and morphotypes, ready to respond to a range of local environmental conditions and to successively fill the niche of those that 'bust' after blooming. The succession of morphotypes and stark contrasts in cell densities within a small region support such patchy and rapid 'boom and bust' scenarios for E. huxleyi in the Benguela upwelling system and highlight the need to collect and distinguish between a range of field data if we want a better understanding of coccolithophore ecology on a global scale.
Acknowledgements. We thank the anonymous reviewers for their careful and constructive feedback. J.H. thanks S. Cook, J. Cubillos, and A. Gerecht for helpful discussions. Sampling during RV 'Meteor' cruise 48, Leg 5 was made possible by grant ME 59/8 by the Deutsche Forschungsgemeinschaft. Coccolithophore research was supported by Swedish Research Council grant VR621-2003-3614 to J.H.

\section{LITERATURE CITED}

Aguilera V, Escribano R, Herrera L (2009) High frequency responses of nanoplankton and microplankton to winddriven upwelling off northern Chile. J Mar Syst 78: $124-135$

Alheit J (2000) Meteor-berichte 06-5, cruise 48, leg 5, Walvis Bay - Walvis Bay, October 13- October 30, 2000. Available at www.dfg-ozean.de/fileadmin/DFG/Berichte/ Report_M48_5KS_.pdf

Astor YM, Scranton MI, Muller-Karger F, Bohrer R, García J (2005) $\mathrm{fCO}_{2}$ variability at the Cariaco tropical coastal upwelling time series station. Mar Chem 97:245-261

Balch WM, Holligan PM, Kilpatrick KA (1992) Calcification, photosynthesis and growth of the bloom-forming coccolithophore Emiliania huxleyi. Cont Shelf Res 12: 1353-1374

Balch WM, Fritz J, Fernandez E (1996) Decoupling of calcification and photosynthesis in the coccolithophore Emiliania huxleyi under steady-state light-limited growth. Mar Ecol Prog Ser 142:87-97

Barlow RG, Cummings DG, Gibb SW (1997) Improved resolution of mono- and divinyl chlorophylls $a$ and $b$ and zeaxanthin and lutein in phytoplankton extracts using reverse phase C-8 HPLC. Mar Ecol Prog Ser 161:303-307

Barlow RG, Aiken J, Moore GF, Holligan PM, Lavender S (2004) Pigment adaptations in surface phytoplankton along the eastern boundary of the Atlantic Ocean. Mar Ecol Prog Ser 281:13-26

> Barlow R, Louw D, Balarin M, Alheit J (2006) Pigment signatures of phytoplankton composition in the northern Benguela ecosystem during spring. Afr J Mar Sci 28: 479-491

Båtvik H, Heimdal BR, Fagerbakke KM, Green JC (1997) Effects of unbalanced nutrient regime on coccolith morphology and size in Emiliania huxleyi (Prymnesiophyceae). Eur J Phycol 32:155-165

> Beaufort L, Heussner S (2001) Seasonal dynamics of calcareous nannoplankton on a west European continental margin: the Bay of Biscay. Mar Micropaleontol 43:27-55

- Beaufort L, Couapel M, Buchet N, Claustre H, Goyet C (2008) Calcite production by coccolithophores in the south east Pacific Ocean. Biogeosciences 5:1101-1117

Beaufort L, Probert I, de Garidel-Thoron T, Bendif EM and others (2011) Sensitivity of coccolithophores to carbonate chemistry and ocean acidification. Nature 476:80-83

Bollmann J, Cortes MY, Haidar AT, Brabec B and others (2002) Techniques for quantitative analyses of calcareous marine phytoplankton. Mar Micropaleontol 44:163-185

Brand L (1994) Physiological ecology of marine coccolithophores. In: Winter A, Siesser WG (eds) Coccolithophores. University Press, Cambridge, p 39-49

> Clark BM (2006) Climate change: a looming challenge for fisheries management in southern Africa. Mar Policy 30: 84-95 
Cook SS, Whittock L, Wright SW, Hallegraeff GM (2011) Photosynthetic pigment and genetic differences between two southern ocean morphotypes of Emiliania huxleyi (Haptophyta). J Phycol 47:615-626

> Cubillos JC, Wright SW, Nash G, de Salas MF and others (2007) Calcification morphotypes of the coccolithophorid Emiliania huxleyi in the Southern Ocean: changes in 2001 to 2006 compared to historical data. Mar Ecol Prog Ser 348:47-54

$>$ Emeis KC, Struck U, Leipe T, Ferdelman TG (2007) Variability in upwelling intensity and nutrient regime in the coastal upwelling system offshore Namibia: results from sediment archives. Int J Earth Sci 98:309-326

Engel A, Zondervan I, Aerts K, Beaufort L and others (2005) Testing the direct effect of $\mathrm{CO}_{2}$ concentration on a bloom of the coccolithophorid Emiliania huxleyi in mesocosm experiments. Limnol Oceanogr 50:493-507

> Feely RA, Sabine CL, Lee K, Berelson W, Kleypas J, Fabry VJ, Millero FJ (2004) Impact of anthropogenic $\mathrm{CO}_{2}$ in the $\mathrm{CaCO}_{3}$ system in the oceans. Science 305:362-366

Feistel R, Hagen E, Grant K (2003) Climate changes in the subtropical Southeast Atlantic: the St. Helena Island Climate Index (1893-1999). Prog Oceanogr 59:321-337

Findlay CS, Giraudeau J (2000) Extant calcareous nannoplankton in the Australian sector of the Southern Ocean (austral summers 1994 and 1995). Mar Micropaleontol 40:417-439

> Giraudeau J, Bailey GW (1995) Spatial dynamics of coccolithophore communities during an upwelling event in the southern Benguela system. Cont Shelf Res 15:1825-1852

Giraudeau J, Monteiro PMS, Nikodemus K (1993) Distribution and malformation of living coccolithophores in the northern Benguela upwelling system off Namibia. Mar Micropaleontol 22:93-110

Grasshoff K, Ehrhardt M, Kremling K (1983) Methods of seawater analysis, 2nd edn. Verlag Chemie, Weinheim

Hagen E, Schemainda R, Michelchen N, Postel L, Schulz S, Below M (1981) Zur Küstensenkrechten Struktur des Kaltwasserauftriebs vor der Küste Namibias. Geod Geophys Veröff 36:1-99

Hagen E, Feistel R, Agenbag JJ, Ohde T (2001) Seasonal and interannual changes in Intense Benguela Upwelling (1982-1999). Oceanol Acta 24:557-568

Hagino K, Okada H, Matsuoka H (2005) Coccolithophore assemblages and morphotypes of Emiliania huxleyi in the boundary zone between the cold Oyashio and warm Kuroshio Currents off the coast of Japan. Mar Micropaleontol 55:19-47

Hansen F, Klingelhoeffer E (eds) (2000) Summary report M48-5 RV Meteor Post Cruise Workshop 1-8 November 2000. National Marine Information and Research Centre (NatMIRC), Swakopmund. Available at www.iowarnemuende.de/tl_files/staff/rfeistel/download/M48-5_ RV-Meteor-Workshopreport.pdf

Iglesias-Rodríguez MD, Schofield O, Batley J, Medlin LK, Hayes PK (2006) Intraspecific genetic diversity in the marine coccolithophore Emiliania huxleyi (Prymnesiophyceae): the use of microsatellite analysis in marine phytoplankton population studies. J Phycol 42:526-536

Iglesias-Rodríguez MD, Halloran PR, Rickaby REM, Hall IR and others (2008) Phytoplankton calcification in a high$\mathrm{pCO}_{2}$ world. Science 320:336-340

Jeffrey SW, Vesk M (1997) Introduction to marine phytoplankton and their pigment structure. In: Jeffrey SW, Mantoura RFC, Wright RW (eds) Phytoplankton pig- ments in oceanography. Guidelines to Modern Methods, Vol. 10. United Nations Educational Scientific and Cultural Organization (UNESCO), Paris

$>$ Kleijne A (1990) Distribution and malformation of extant calcareous nannoplankton in the Indonesian Seas. Mar Micropaleontol 16:293-316

- Kuypers MMM, Lavik G, Woebken D, Schmid M and others (2005) Massive nitrogen loss from the Benguela upwelling system through anaerobic ammonium oxidation. Proc Natl Acad Sci USA 102:6478-6483

Langer G, Nehrke G, Probert I, Ly J, Ziveri P (2009) Strainspecific responses of Emiliania huxleyi to changing seawater carbonate chemistry. Biogeosciences 6:2637-2646

McIntyre A, Bé AWH (1967) Modern coccolithophoridae of the Atlantic Ocean 1. Placoliths and cyrtoliths. Deep-Sea Res 14:561-597

> Medlin LK, Barker GLA, Campbell L, Green JC and others (1996) Genetic characterisation of Emiliania huxleyi (Haptophyta). J Mar Syst 9:13-31

> Mitchell-Innes BA, Winter A (1987) Coccolithophores: a major phytoplankton component in mature upwelled waters off the Cape Peninsula, South Africa in March, 1983. Mar Biol 95:25-30

Okada H, Honjo S (1973) The distribution of oceanic coccolithophorids in the Pacific. Deep-Sea Res 20:355-374

Orr JC, Fabry VJ, Aumont O, Bopp L and others (2005) Anthropogenic ocean acidification over the twenty-first century and its impact on calcifying organisms. Nature 437:681-686

Paasche E (2001) A review of the coccolithophorid Emiliania huxleyi (Prymnesiophyceae), with particular reference to growth, coccolith formation, and calcification-photosynthesis interactions. Phycologia 40:503-529

Pitcher GC, Walker DR, Mitchell-Innes BA, Moloney CL (1991) Short-term variability during an anchor station study in the southern Benguela upwelling system: phytoplankton dynamics. Prog Oceanogr 28:39-64

> Poulton AJ, Adey TR, Balch WM, Holligan PM (2007) Relating coccolithophore calcification rates to phytoplankton community dynamics: regional differences and implications for carbon export. Deep-Sea Res II 54:538-557

Riebesell U, Revill A, Holdsworth DG, Volkman JK (2000) The effects of varying $\mathrm{CO}_{2}$ concentration on lipid composition and carbon isotope fractionation in Emiliania huxleyi. Geochim Cosmochim Acta 64:4179-4192

Rohde KH, Nehring D (1979) Ausgewählte Methoden zur Bestimmung von Inhaltsstoffen im Meer- und Brackwasser. Geod Geophys Veröff (Reihe IV) 27:1-68

Rost B, Zondervan I, Wolf-Gladrow DA (2008) Sensitivity of phytoplankton to future changes in ocean carbonate chemistry: current knowledge, contradictions and research directions. Mar Ecol Prog Ser 373:227-237

> Santana-Casiano JM, González-Dávila M, Ucha IR (2009) Carbon dioxide fluxes in the Benguela upwelling system during winter and spring: a comparison between 2005 and 2006. Deep-Sea Res II 56:533-541

Schroeder DC, Biggi GF, Hall M, Davy J and others (2005) A genetic marker to separate Emiliania huxleyi (Prymnesiophyceae) morphotypes. J Phycol 41:874-879

Shannon LV (1985) The Benguela ecosystem part I. Evolution of the Benguela, physical features and processes. Oceanogr Mar Biol Annu Rev 23:105-182

Siegel H, Ohde T, Gerth M, Lavik G, Leipe T (2007) Identification of coccolithophore blooms in the SE Atlantic ocean of Namibia by satellites and in-situ methods. Cont 
Shelf Res 27:258-274

Smyth TJ, Tyrrel T, Tarrant B (2004) Time series of coccolithophore activity in the Barents Sea, from twenty years of satellite imagery. Geophys Res Lett 31:L11302 doi: 10.1029/2004GL019735

Thierstein HR, Geitzenauer KR, Molfino B, Shackleton NJ (1977) Global synchroneity of late Quaternary coccolith datum levels: validation by oxygen isotopes. Geology 5: 400-404

Van Bleijswijk J, Van der Wal P, Kempers R, Veldhuis M and others (1991) Distribution of two types of Emiliania huxleyi (prymnesiophyceae) in the northeast Atlantic region as determined by immunofluorescence and coccolith morphology. J Phycol 27:566-570

Van Lenning K, Probert I, Latasa M, Estrada M, Young JR (2004) Pigment diversity of coccolithophores in relation to taxonomy, phylogeny and ecological preferences. In: Thierstein HR, Young JR (eds) Coccolithophores: from molecular processes to global impact. Springer-Verlag, Berlin, p 51-73

Weeks SJ, Pitcher GC, Bernard S (2004) Satellite monitoring of the evolution of a coccolithophorid bloom in the south-

Editorial responsibility: Antonio Bode, A Coruña, Spain ern Benguela Upwelling System. Oceanography 17: 83-89

Winter A (1985) Distribution of living coccolithophores in the California Current system, Southern California Borderland. Mar Micropaleontol 9:385-393

Yang TN, Wei KY, Chen MP, Ji SJ, Gong GC, Lin FJ, Lee TQ (2004) Summer and winter distribution and malformation of coccolithophores in the East China Sea. Micropaleontology 50:157-170

Young JR (1994) Variation in Emiliania huxleyi coccolith morphology in samples from the Norwegian Ehux experiment, 1992. Sarsia 79:417-425

Young J, Westbroek P (1991) Genotypic variation in the coccolithophorid species Emiliania huxleyi. Mar Micropaleontol 18:5-23

Young J, Geisen M, Cros L, Kleijne A, Sprengel C, Probert I, Østergaard J (2003) A guide to extant coccolithophore taxonomy. J Nannoplankton Res (Spec Issue) 1:1-125

Zondervan I (2007) The effects of light, macronutrients, trace metals and $\mathrm{CO}_{2}$ on the production of calcium carbonate and organic carbon in coccolithophores - a review. Deep-Sea Res II 54:521-530

Submitted: July 15, 2011; Accepted: November 30, 2011

Proofs received from author(s): February 8, 2012 